\title{
Haemodynamic goal-directed therapy and postoperative infections: earlier is better. a systematic review and meta-analysis
}

\author{
Lidia Dalfino, Maria T Giglio, Filomena Puntillo, Massimo Marucci and Nicola Brienza*
}

\begin{abstract}
Introduction: Infectious complications are the main causes of postoperative morbidity. The early timing of their promoting factors is the rationale for perioperative strategies attempting to reduce them. Our aim was to determine the effects of perioperative haemodynamic goal-directed therapy on postoperative infection rates.

Methods: We performed a systematic review and meta-analysis. MEDLINE, EMBASE, The Cochrane Library and the DARE databases were searched up to March 2011. Randomised, controlled trials of major surgery in adult patients managed with perioperative goal-directed therapy or according to routine haemodynamic practice were included. Primary outcome measure was specific type of infection.

Results: Twenty-six randomised, controlled trials with a combined total of 4,188 participants met our inclusion criteria. Perioperative goal-directed therapy significantly reduced surgical site infections (pooled OR 0.58, 95\% Cl 0.46 to $0.74 ; P<0.0001$ ), pneumonia (pooled $\mathrm{OR} 0.71,95 \% \mathrm{Cl} 0.55$ to $0.92 ; P=0.009$ ), and urinary tract infections (pooled OR $0.44,95 \% \mathrm{Cl} 0.22$ to $0.84 ; P=0.02$ ). A significant benefit was found regarding total infectious episodes (OR $0.40,95 \% \mathrm{Cl} 0.28$ to $0.58 ; P<0.00001$ ).

Conclusions: Flow-directed haemodynamic therapy designed to optimise oxygen delivery protects surgical patients against postoperative hospital-acquired infections and must be strongly encouraged, particularly in the high-risk surgical population.
\end{abstract}

\section{Introduction}

In major surgical patients, infectious complications are the main cause of morbidity $[1,2]$. Other than strict asepsis, antibiotic prophylaxis, avoidance of glucose imbalance, and normothermia [3], no strategy has been demonstrated to be effective for their prevention. Even though postoperative infections are typically not detected until a few days after surgery, their promoting factors occur within the first few hours following surgical insult.

Goal-directed therapy (GDT) is a haemodynamic treatment based on titration of fluid and inotropic drugs infused to physiologic flow-related end points [4]. This regimen was originally applied in surgical patients with the aim of reaching normal or supranormal values of

\footnotetext{
* Correspondence: nbrienza@rianima.uniba.it

Anesthesia and Intensive Care Unit, Department of Emergency and Organ Transplantation, University of Bari, Piazza G. Cesare 11, I-70124 Bari, Italy
}

cardiac output and oxygen delivery $\left(\mathrm{DO}_{2}\right)$ to manage the perioperative increase in oxygen demand and to prevent organ failure [5]. When performed perioperatively in high-risk surgical patients, GDT decreases mortality [6] and postoperative renal and gastrointestinal complications $[7,8]$. However, no study on perioperative GDT has specifically assessed postoperative infections as the main primary outcome measure.

Therefore, we performed a systematic review including a meta-analysis about the effects of perioperative GDT on postoperative infections. We reviewed randomised, controlled trials (RCTs) to assess the efficacy of GDT compared with standard haemodynamic management of postoperative infections in adult surgical patients.

\section{Materials and methods \\ Eligibility criteria}

Studies were searched according to the following eligibility criteria [9]:

\section{()


1. Types of participants: Adult patients (ages 18 years and older) undergoing major surgery were considered. Studies involving mixed populations of critically ill, nonsurgical patients, or postoperative patients with sepsis or organ failure were excluded.

2. Types of interventions: GDT was defined as perioperative monitoring and manipulation of haemodynamic parameters to reach normal or supranormal values by fluid infusion alone or in combination with inotropic therapy within eight hours after surgery. Studies including late haemodynamic optimisation treatment were excluded.

3. Types of comparisons: Trials comparing the beneficial and harmful effects of GDT and standard haemodynamic therapy were considered. We excluded RCTs with no description of or no difference in optimisation strategies between groups, as well as RCTs in which therapy was titrated to the same goal in both groups or was not titrated to predefined end points.

4. Types of outcome measures: The primary outcome measures were surgical site infections (SSIs), either incisional and organ or space; pneumonia; catheter-related bloodstream infections (CRBSIs), and urinary tract infections (UTIs). The secondary outcome measure was the number of overall postoperative infectious episodes.

5. Types of studies: RCTs on perioperative GDT in surgical patients were included. No language, publication date, or publication status restrictions were imposed.

\section{Information sources}

Different search strategies (last update March 2011) were performed to retrieve relevant studies by using the MEDLINE, The Cochrane Library and EMBASE databases. No date restriction was applied for searching the MEDLINE and The Cochrane Library databases, while the search was limited to 2007 to 2011 for searching of the EMBASE database [10]. Additional RCTs were searched in The Cochrane Library and the Database of Abstracts of Reviews of Effects (DARE) databases and in the reference lists of previously published reviews and retrieved articles. Other data sources were handsearched in the annual proceedings (2003 to 2010) of the Society of Critical Care Medicine, the European Society of Intensive Care Medicine, the Society of Cardiovascular Anesthesiologists, the Royal College of Anaesthetists and the American Society of Anesthesiologists.

\section{Search terms}

Trials selection was performed by using the following search terms: randomized controlled trial, controlled clinical trial, surgery, goal directed, goal oriented, goal target, cardiac output, cardiac index, $\mathrm{DO}_{2}$, oxygen consumption, cardiac volume, stroke volume, fluid therapy, fluid loading, fluid administration, optimisation, optimization, sopranormal, supranormal.

The search strategies used for the MEDLINE, The Cochrane Library and EMBASE databases are reported in Additional file 1.

\section{Study selection}

Two investigators (MM and LD) first examined each title and abstract to exclude clearly irrelevant studies and to identify potentially relevant articles. Other two investigators (MG and FP) independently determined the eligibility of full-text articles retrieved. The names of the authors, institutions, and the journals in which the articles were published, as well as the RCT's results, were unknown to the two investigators at that time.

\section{Data collection process}

Data were independently collected by two investigators (MG and NB), with any discrepancy being resolved by reinspection of the original article. To avoid transcription errors, the data were input into statistical software and rechecked by different investigators (FP and LD).

\section{RCT data gathered}

Data abstraction included patient characteristics (age and sex) and risk factors (based on Physiologic and Operative Severity Score for the Enumeration of Mortality and Morbidity - POSSUM score [11], American Society of Anesthesiologists Physical Status classification, age $>60$ years and preoperative morbidity), type of surgery (that is, elective or emergent, abdominal, thoracic, vascular and so forth), type of haemodynamic GDT (monitoring tools, haemodynamic end points and therapeutic interventions), incidence (number of infected patients and number of infectious episodes) and definition of postoperative infections.

\section{Risk of bias in individual studies}

The Scottish Intercollegiate Guidelines Network (SIGN) checklist for RCTs was used to evaluate the methodological quality of the RCTs. The SIGN checklist was independently filled in by two investigators (MG and MM) and whenever their results differed, the study was further assessed to reach consensus. In Table 1, a double-plus sign $(++)$ denotes studies very unlikely to have bias, a single plus sign $(+)$ indicates studies in which bias is unlikely and a minus sign (-) denotes studies with a high risk of bias [12]. A doubleplus sign was assigned to studies that adequately fit all the criteria of randomisation, concealment, blinding, intention-to-treat analysis and predefined outcomes. A single plus sign was given to studies meeting only four of the five criteria. The adequacy of these five criteria is strongly associated with bias reduction $[13,14]$. 
Table 1 Quality assessment, sample characteristics and intervention details of the included studies ${ }^{\mathrm{a}}$

\begin{tabular}{|c|c|c|c|c|c|c|}
\hline Study & $\begin{array}{l}\text { SIGN } \\
\text { score }\end{array}$ & SIGN comment & $\begin{array}{c}\text { Risk } \\
\text { definition }\end{array}$ & Type of surgery & $\begin{array}{l}\text { Goal-directed therapy } \\
\text { (tools and goals) }\end{array}$ & $\begin{array}{l}\text { Modality of } \\
\text { optimisation }\end{array}$ \\
\hline $\begin{array}{l}\text { Bender et al. } 1997 \\
\text { [21], USA }\end{array}$ & - & $\begin{array}{l}\text { Randomisation and concealment not } \\
\text { clear, not blinded }\end{array}$ & & Elective aortic and vascular & $\begin{array}{l}\text { PAC: } \mathrm{Cl} \geq 2.8 \mathrm{~L} / \mathrm{minute} / \mathrm{m}^{2}, 8 \leq \mathrm{PCWP} \leq 14 \mathrm{mmHg} \text {, SVR } \\
\leq 1,100 \mathrm{dyn} / \mathrm{second} / \mathrm{cm}^{5}\end{array}$ & $\begin{array}{l}\text { Fluids and } \\
\text { inotropes }\end{array}$ \\
\hline $\begin{array}{l}\text { Benes et al. } 2010 \\
\text { [22], Europe }\end{array}$ & ++ & & High risk & Major abdominal & Vigileo monitor/FloTrac sensor: SW < 10\% & $\begin{array}{l}\text { Fluids and } \\
\text { inotropes }\end{array}$ \\
\hline $\begin{array}{l}\text { Bishop et al. } 1995 \\
\text { [23], USA }\end{array}$ & - & $\begin{array}{l}\text { Randomisation not adequate, } \\
\text { concealment not clear, not blinded }\end{array}$ & High risk & Emergent trauma & $\begin{array}{l}\mathrm{PAC}: \mathrm{Cl} \geq 4.5 \mathrm{~L} / \text { minute } / \mathrm{m}^{2}, \mathrm{DO}_{2} \geq 670 \mathrm{~mL} / \text { minute } / \mathrm{m}^{2} \\
\mathrm{VO}_{2} \geq 166 \mathrm{~mL} / \mathrm{minute} / \mathrm{m}^{2}\end{array}$ & $\begin{array}{l}\text { Fluids and } \\
\text { inotropes }\end{array}$ \\
\hline $\begin{array}{l}\text { Boyd et al. } 1993 \\
\text { [24], Europe }\end{array}$ & - & $\begin{array}{l}\text { Randomisation and concealment not } \\
\text { clear }\end{array}$ & High risk & $\begin{array}{l}\text { Emergent or elective } \\
\text { major abdominal or vascular }\end{array}$ & $\mathrm{PAC}: \mathrm{DO}_{2}>600 \mathrm{~mL} /$ minute $/ \mathrm{m}^{2}$ & $\begin{array}{l}\text { Fluids and } \\
\text { inotropes }\end{array}$ \\
\hline $\begin{array}{l}\text { Chytra et al. } 2007 \\
\text { [25], Europe }\end{array}$ & + & Randomisation not clear & High risk & Emergent trauma & $\begin{array}{l}\text { Oesophageal Doppler: SV optimisation with FTc }>0.35 \\
\text { seconds }\end{array}$ & $\begin{array}{l}\text { Fluids } \\
\text { (noradrenaline } \\
\text { intraoperatively) }\end{array}$ \\
\hline $\begin{array}{l}\text { Fleming et al. } 1992 \\
\text { [26], USA }\end{array}$ & - & $\begin{array}{l}\text { Randomisation not adequate, not } \\
\text { blinded, concealment not described }\end{array}$ & High risk & Emergent trauma & $\begin{array}{l}\mathrm{PAC}: \mathrm{Cl} \geq 4.5 \mathrm{~L} / \text { minute } / \mathrm{m}^{2}, \mathrm{DO}_{2} \geq 670 \mathrm{~mL} / \text { minute } / \mathrm{m}^{2}, \\
\mathrm{VO}_{2} \geq 166 \mathrm{~mL} / \text { minute } / \mathrm{m}\end{array}$ & $\begin{array}{l}\text { Fluids and } \\
\text { inotropes }\end{array}$ \\
\hline $\begin{array}{l}\text { Forget et al. } 2010 \\
\text { [27], Europe }\end{array}$ & ++ & & High risk & Major abdominal & Masimo SET pulse oximeter: PVI > 13\% & Fluids \\
\hline $\begin{array}{l}\text { Gan et al. } 2002[28] \\
\text { USA }\end{array}$ & ++ & & & $\begin{array}{l}\text { Elective general, urologic, } \\
\text { gynaecologic }\end{array}$ & $\begin{array}{l}\text { Oesophageal Doppler: SV optimisation with FTc between } \\
0.35 \text { and } 0.4 \text { seconds }\end{array}$ & Fluids \\
\hline $\begin{array}{l}\text { Jhanji et al. } 2010 \\
\text { [29], Europe }\end{array}$ & ++ & & High risk & Major elective abdominal & LiDCO Cardiac Sensor System: SV > 10\% & Fluids \\
\hline $\begin{array}{l}\text { Lobo et al. } 2000 \\
\text { [30], Brazil }\end{array}$ & + & Randomisation not clear & High risk & Elective major abdominal or vascular & PAC: $\mathrm{DO}_{2}>600 \mathrm{~mL} /$ minute $/ \mathrm{m}^{2}$ & Fluids \\
\hline $\begin{array}{l}\text { Lopes et al. } 2007 \\
\text { [31], Brazil }\end{array}$ & + & Randomisation not clear & High risk & Elective abdominal & Radial artery line: $\triangle \mathrm{PP} \leq 10 \%$ & Fluids \\
\hline $\begin{array}{l}\text { Mayer et al. } 2010 \\
\text { [32], Europe }\end{array}$ & + & Randomisation not clear & High risk & Major abdominal & Vigileo monitor/FloTrac sensor: $\mathrm{Cl} \geq 2.5 \mathrm{~L} /$ minute/m² & $\begin{array}{l}\text { Fluids and } \\
\text { inotropes }\end{array}$ \\
\hline $\begin{array}{l}\text { McKendry et al. } \\
2004 \text { [33], Europe }\end{array}$ & + & Complication not defined & & Elective cardiac & Oesophageal Doppler: $\mathrm{SI}>35 \mathrm{~mL} / \mathrm{m}^{2}$ & Fluids \\
\hline $\begin{array}{l}\text { Mythen and Webb } \\
1995 \text { [34], Europe }\end{array}$ & - & $\begin{array}{l}\text { Randomisation not clear, flow of } \\
\text { patients not described }\end{array}$ & High risk & Elective cardiac & $\begin{array}{l}\text { Oesophageal Doppler: } \\
\text { SV optimisation and rise in CVP }<3 \mathrm{mmHg}\end{array}$ & Fluids \\
\hline
\end{tabular}


Table 1 Quality assessment, sample characteristics and intervention details of the included studies ${ }^{\text {a }}$ (Continued)

\begin{tabular}{|c|c|c|c|c|c|c|}
\hline $\begin{array}{l}\text { Noblett et al. } 2006 \\
\text { [35], Europe }\end{array}$ & + & Randomisation not clear & & Colorectal & $\begin{array}{l}\text { Oesophageal Doppler: SV optimisation with FTc between } \\
0.35 \text { and } 0.4 \text { seconds }\end{array}$ & $\begin{array}{l}\text { Fluids } \\
\text { (catecholamines } \\
\text { intraoperatively) }\end{array}$ \\
\hline $\begin{array}{l}\text { Pearse et al. } 2005 \\
\text { [36], Europe }\end{array}$ & ++ & & High risk & Elective or emergent major general & $\begin{array}{l}\text { LiDCO Cardiac Sensor System: } \mathrm{DO}_{2}>600 \mathrm{~mL} / \text { minute/ } \\
\mathrm{m}^{2}, \mathrm{SV}>10 \%\end{array}$ & $\begin{array}{l}\text { Fluids and } \\
\text { inotropes }\end{array}$ \\
\hline $\begin{array}{l}\text { Sandham et al. } 2003 \\
\text { [37], Canada }\end{array}$ & ++ & & High risk & $\begin{array}{l}\text { Elective or emergent major } \\
\text { abdominal, thoracic, vascular, or } \\
\text { orthopaedic }\end{array}$ & $\begin{array}{l}\mathrm{PAC}: \mathrm{Cl}>3.5 \text { and }<4.5 \mathrm{~L} / \mathrm{minute} / \mathrm{m}^{2}, 550<\mathrm{DO}_{2}<600 \\
\mathrm{~mL} / \mathrm{minute} / \mathrm{m}^{2}, \mathrm{MAP}>70 \mathrm{mmHg}, \mathrm{PCWP}<18 \mathrm{mmHg}\end{array}$ & $\begin{array}{l}\text { Fluids and } \\
\text { inotropes }\end{array}$ \\
\hline $\begin{array}{l}\text { Shoemaker et al. } \\
1998 \text { [38], USA }\end{array}$ & - & $\begin{array}{l}\text { Not blinded, unclear dropouts and } \\
\text { withdrawals }\end{array}$ & High risk & $\begin{array}{l}\text { Emergent or elective major } \\
\text { abdominal } \\
\text { (general or vascular) }\end{array}$ & $\begin{array}{l}\mathrm{PAC}: \mathrm{Cl}>4.5 \mathrm{~L} / \text { minute } / \mathrm{m}^{2}, \mathrm{DO}_{2}>600 \mathrm{~mL} / \text { minute } / \mathrm{m}^{2} \text {, } \\
\mathrm{VO}_{2}>170 \mathrm{~mL} / \text { minute } / \mathrm{m}^{2}\end{array}$ & $\begin{array}{l}\text { Fluids and } \\
\text { inotropes }\end{array}$ \\
\hline $\begin{array}{l}\text { Sinclair et al. } 1997 \\
\text { [39], Europe }\end{array}$ & - & $\begin{array}{l}\text { Randomisation and concealment not } \\
\text { clear, flow of patients not described }\end{array}$ & High risk & Orthopaedic & $\begin{array}{l}\text { Oesophageal Doppler: SV optimisation with FTc between } \\
0.35 \text { and } 0.4 \text { seconds }\end{array}$ & Fluids \\
\hline $\begin{array}{l}\text { Smetkin et al. } 2009 \\
\text { [40], Europe }\end{array}$ & - & $\begin{array}{l}\text { Randomisation not adequate, not } \\
\text { blinded, concealment not described }\end{array}$ & & Elective cardiac & $\begin{array}{l}\text { PiCCO Plus monitor: ITBVI } 850 \text { to } 1,000 \mathrm{~mL} / \mathrm{m}, \mathrm{ScvO}_{2}> \\
60 \%\end{array}$ & $\begin{array}{l}\text { Fluids and } \\
\text { inotropes }\end{array}$ \\
\hline $\begin{array}{l}\text { Valentine et al. } 1998 \\
\text { [41], USA }\end{array}$ & - & Randomisation not clear, not blinded & & Elective aortic & $\begin{array}{l}\text { PAC: } \mathrm{Cl} \geq 2.8 \mathrm{~L} / \mathrm{minute} / \mathrm{m}^{2}, 8 \leq \mathrm{PCWP} \leq 15 \mathrm{mmHg} \text {, SVR } \\
\leq 1,100 \mathrm{dyn} / \mathrm{second} / \mathrm{cm}^{5}\end{array}$ & $\begin{array}{l}\text { Fluids and } \\
\text { inotropes }\end{array}$ \\
\hline $\begin{array}{l}\text { Van der Linden et } \\
\text { al. } 2010 \text { [42], Europe }\end{array}$ & ++ & & High risk & Vascular & Vigileo monitor/FloTrac sensor: $\mathrm{Cl}>2.5 \mathrm{~L} /$ minute $/ \mathrm{m}^{2}$ & $\begin{array}{l}\text { Fluids and } \\
\text { inotropes }\end{array}$ \\
\hline $\begin{array}{l}\text { Velmahos et al. } \\
2000 \text { [43], USA }\end{array}$ & + & Not blinded & High risk & Emergent trauma & Thoracic bioimpedance: $\mathrm{Cl}>4.5 \mathrm{~L} /$ minute $/ \mathrm{m}^{2}$ & $\begin{array}{l}\text { Fluids and } \\
\text { inotropes }\end{array}$ \\
\hline $\begin{array}{l}\text { Venn et al. } 2002 \\
\text { [44], Europe }\end{array}$ & ++ & & High risk & Orthopaedic & $\begin{array}{l}\text { Oesophageal Doppler: SV optimisation with FTc > } 0.4 \\
\text { seconds }\end{array}$ & Fluids \\
\hline $\begin{array}{l}\text { Wakeling et al. } 2005 \\
\text { [45], Europe }\end{array}$ & ++ & & & Elective major bowel & $\begin{array}{l}\text { Oesophageal Doppler: SV optimisation and rise in CVP }< \\
3 \mathrm{mmHg}\end{array}$ & Fluids \\
\hline $\begin{array}{l}\text { Wilson et al. } 1999 \\
\text { [46], Europe }\end{array}$ & + & Not blinded & High risk & $\begin{array}{l}\text { Elective major (abdominal, vascular, } \\
\text { urologic) }\end{array}$ & PAC: $\mathrm{DO}_{2}>600 \mathrm{~mL} /$ minute $/ \mathrm{m}^{2}$ & $\begin{array}{l}\text { Fluids and } \\
\text { inotropes }\end{array}$ \\
\hline
\end{tabular}


Regarding blinding, those studies in which the outcome was explicitly predefined, the outcome assessment was blinded, or both, were considered adequately masked [15]. For every site of infection, a quality-sensitive analysis was performed, including studies with a low risk of bias (SIGN evaluation ++ or + ) and those with a high risk of bias (SIGN evaluation -), and a subgroup analysis was planned that included only trials that enrolled high-risk patients. Moreover, an outcome-level assessment (sensitivity analysis) was performed, including studies providing definitions consistent with the Centers for Disease Control and Prevention (CDC) criteria [16].

\section{Summary measures and planned method of analysis}

Meta-analytic techniques (RevMan analytical software version 5.1.1; Cochrane Collaboration, Oxford, UK) were used to combine studies using odds ratios (ORs) and $95 \%$ confidence intervals (95\% CIs). A statistical difference between groups was considered to have occurred if the pooled $95 \%$ CI did not include 1 for the OR. An OR less than 1 favoured GDT compared with control group. Two-sided $P$ values were calculated. A random effects model was chosen for all analyses. Statistical heterogeneity and inconsistency were assessed by using the Q-test and $I^{2}$ test, respectively $[17,18]$. When the $P$ value of the $\mathrm{Q}$-test was $<0.10$ and/or the $I^{2}$ was $>40 \%$, heterogeneity and inconsistency were considered significant [19]. When significant heterogeneity and inconsistency were found, the most heterogeneous study on the basis of the forest plot was removed and the analysis was redone [20]. In all main analyses, studies comprising more than half the pooled number of patients were removed and reanalysis was performed.

For each main outcome measure, calculation of the number of patients needed to treat (NNT with $95 \% \mathrm{CI}$ ) to prevent one patient with complications was carried out using the formula NNT $=1 /(\mathrm{RRR} \times \mathrm{CER})$, where $R R R$ is the summary relative risk reduction and CER is the control event rate for all trials. Statistical power with an $\alpha$ error of 0.05 was calculated for each main analysis, and results $\geq 80 \%$ were considered adequate.

\section{Results}

\section{Study selection}

The search strategies that we used identified 2,676 (MEDLINE), 8,545 (Cochrane Library) and 795 (EMBASE) articles. After initial screening and subsequent more detailed selection, a pool of 63 potentially relevant RCTs was identified. The eligibility process (Figure 1) excluded 37 articles, and therefore 26 RCTs [21-46] enrolling a total sample of 4,188 patients were included in our meta-analysis.

\section{Study characteristics}

All selected articles described the results of RCTs evaluating the effects of GDT on postoperative morbidity, including infections as primary or secondary outcomes, and had a population sample of adult patients undergoing major surgical procedures. Of 26 studies, 21 studies [21-32,35-38,41-43,45,46] included abdominal surgery, 3 studies $[33,34,40]$ involved cardiac procedures and two studies $[39,44]$ included only orthopaedic surgery.

During the period from 1993 to 2010, 16 studies were performed in Europe [22,24,25,27,29,32-36,39,42,44-46], 7 were conducted in the United States [21,23, 26,28,38,41,43], 2 were carried out in Brazil [31,32] and 1 was performed in Canada [37]. Eighteen studies reported the incidence of SSIs, fifteen reported the incidence of pneumonia, five reported the incidence of CRBSIs, and ten reported the incidence of UTIs. Nineteen studies had enrolled high-risk patients, and seventeen studies had received a SIGN evaluation of + or ++ (see Table 1 for details).

\section{Quantitative data synthesis \\ SSIs}

A total of 320 episodes of SSI were registered: 199 (11\%) of 1,793 occurred in patients randomised to control treatment and 121 (6.9\%) of 1,757 occurred in patients randomised to the perioperative GDT group. The pooled OR was 0.58 and the pooled $95 \%$ CI was 0.46 to 0.74 (3,550 patients from 18 RCTs; statistical power $100 \%$ ). The NNT was 24 (95\% CI 16.4 to 42.8 ). No statistical heterogeneity or inconsistency was detected (Figure 2). After excluding the largest study [37], the pooled OR was 0.41 with a pooled $95 \% \mathrm{CI}$ of 0.29 to $0.59(P<$ $0.00001)$ for 1,644 patients, with no statistical heterogeneity found ( $Q$ statistic $P=0.90 ; I^{2}=0 \%$ ). The beneficial effect of GDT in reducing SSIs was confirmed by the quality-sensitive analysis (that is, including only studies with a low risk of bias) (Figure 2).

\section{Pneumonia}

A total of 283 episodes of postoperative pneumonia were registered: $162(10 \%)$ of 1,590 occurred in the control group and 121 (7.5\%) of 1,605 occurred in the GDT group. The pooled OR was 0.71 and the pooled $95 \%$ CI was 0.55 to 0.92 (from a total of 3,195 patients in 15 RCTs; statistical power $86 \%)$. The NNT was 34 (95\% CI 20.8 to 91.6$)$. No statistical heterogeneity or inconsistency was detected (Figure 3). Excluding the largest study [37] yielded a pooled OR of 0.54 with a pooled $95 \%$ CI of 0.38 to 0.78 (from a total of 1,289 patients, $P$ $=0.001 ; Q$ statistic $P=0.99 ; I^{2}=0 \%$ ). The quality-sensitive analysis confirmed the positive effect of GDT in studies with a low risk of bias (Figure 3). 


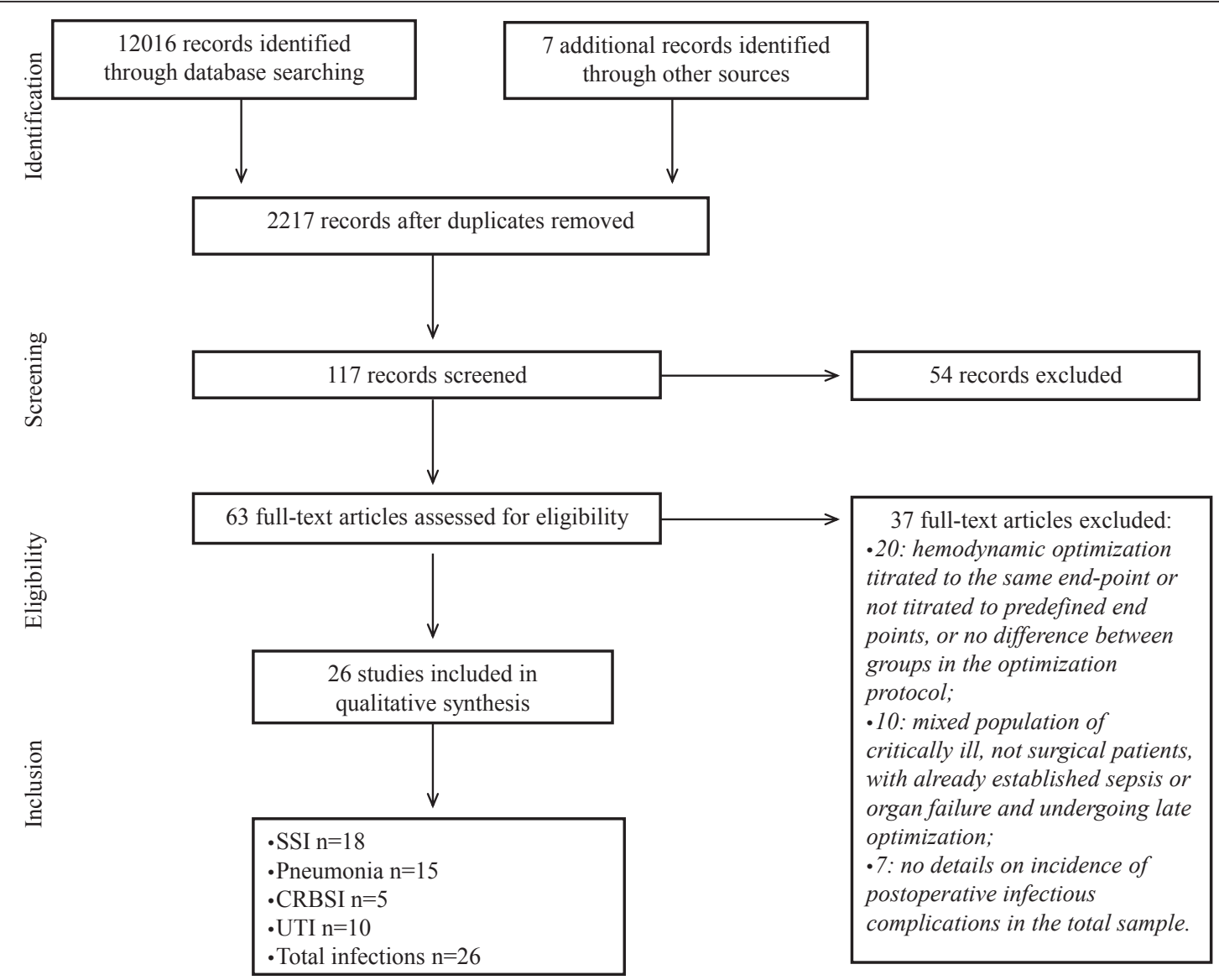

Figure 1 Outline of studies selection process. Flowchart summarising the procedure of studies selection for the meta-analysis. CRBSI: catheter-related bloodstream infection; SSI: surgical site infection; UTI: urinary tract infection.

\section{CRBSIs}

In five RCTs, fifty-four patients developed CRBSIs: 33 (2.7\%) of 1,213 had been randomised to control group and $21(1.7 \%)$ of 1,235 had been randomised to perioperative GDT group. GDT did not reduce the incidence of CRBSIs. The pooled OR was 0.63 (pooled 95\% CI 0.31 to 1.28 ; statistical power $39 \%$ ).

\section{UTIs}

In 10 RCTs, 44 patients developed UTIs: 31 (6.9\%) of 449 had been randomised to control group and 13 $(2.8 \%)$ of 458 had been randomised to perioperative GDT group. GDT reduced the incidence of UTIs: the pooled OR was 0.44 (pooled 95\% CI 0.22 to 0.88 ; statistical power $82 \%$ ). The NNT was 25 (95\% CI 14.6 to 78.7). No statistical heterogeneity or inconsistency was detected (Figure 4).

The quality-sensitive analysis confirmed the positive effect of GDT in studies with a low risk of bias (Figure 4). The subgroup analyses (including only high-risk patients) and the sensitivity analyses (which included studies providing definitions consistent with the CDC criteria) confirmed the main results for SSIs, pneumonia and UTIs (Table 2).

\section{All infectious episodes}

In the 26 RCTs, 909 infectious events were reported: $550(26 \%)$ in the 2,115 patients randomised to control group and 359 (17.3\%) in the 2,073 patients randomised to perioperative GDT group. The pooled OR for the development of infection was 0.40 (pooled 95\% CI 0.28 to 0.58 ; statistical power $100 \%$ ). The NNT was 12 (95\% CI 9.0 to 16.1 ). Statistically significant heterogeneity and inconsistency were detected (Figure 5). After excluding the largest study [37], leaving a combined sample of 2,282 patients, the pooled OR was 0.38 and the pooled $95 \% \mathrm{CI}$ was 0.26 to $0.56(P<0.0001)$, but statistically significant heterogeneity was still observed. Excluding the two most heterogeneous studies [22,36] yielded a pooled OR of 0.53 with a pooled $95 \%$ CI of 0.40 to 0.70 in a combined sample of 3,946 patients $(P$ $<0.00001$; statistical power $99 \%)$ and moderate statistical heterogeneity and inconsistency $(Q$ statistic $P=$ $\left.0.05 ; I^{2}=34 \%\right)$. 


\section{Surgical site infections}

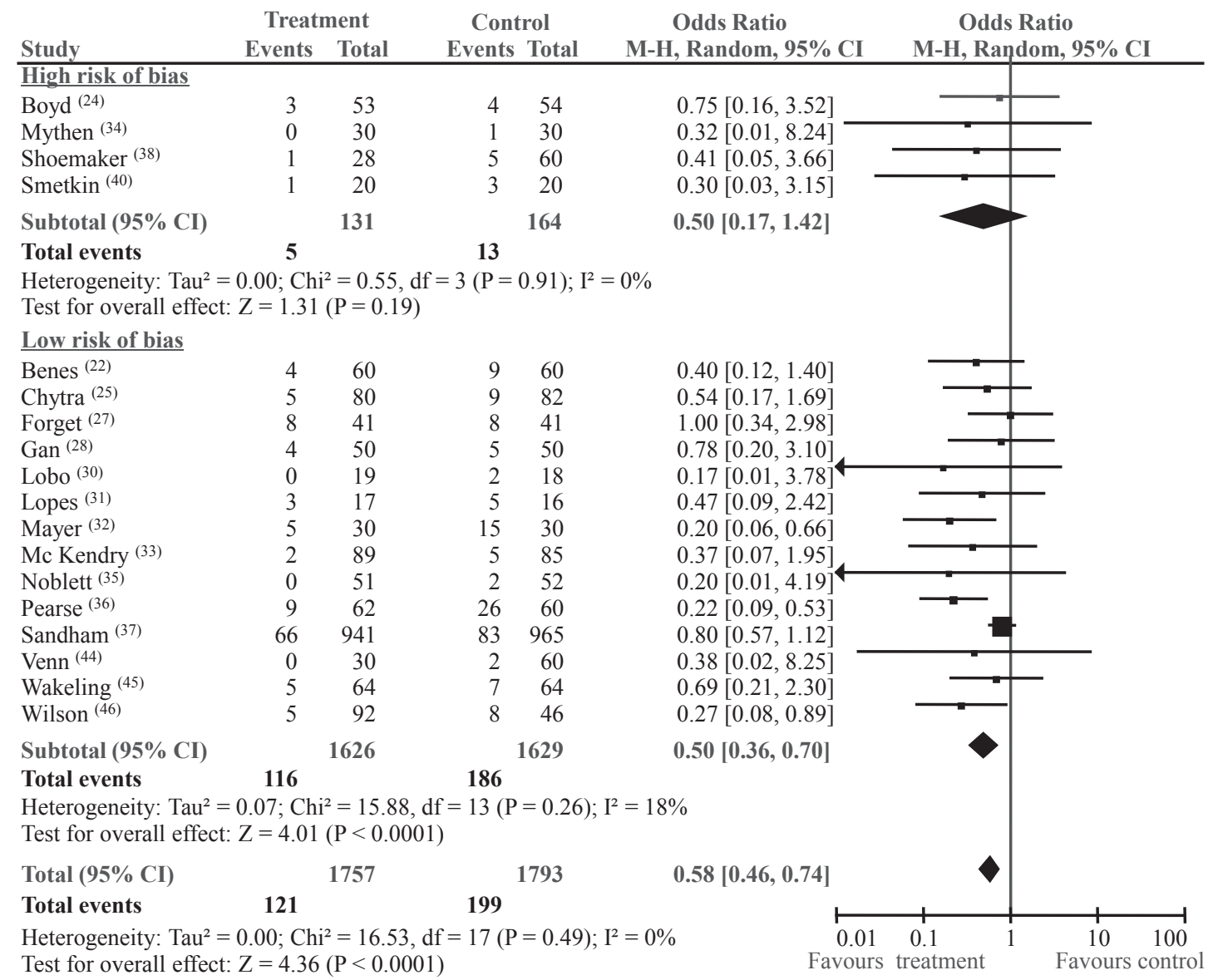

Figure 2 Surgical site infections. Rates of postoperative surgical site infections for each of the studies with OR and $95 \% \mathrm{Cl}$ data are shown. The studies were divided into two subgroups, high risk of bias or low risk of bias, according to the SIGN checklist (see materials and methods section for details). The pooled $\mathrm{OR}$ and $95 \% \mathrm{Cl}$ data are shown as the totals. The size of the box at the point estimate of the OR is a visual representation of the 'weighting' of the study. The diamond represents the point estimate of the pooled OR, and the length of the diamond is proportional to the $95 \% \mathrm{Cl}$. 95\% Cl: $95 \%$ confidence interval; M-H: Mantel-Hentzel; OR: odds ratio; SIGN: Scottish Intercollegiate Guidelines Network.

\section{Discussion}

Patients who undergo major surgery and are managed with perioperative haemodynamic GDT are protected against hospital-acquired infectious events. Specifically, GDT decreases SSIs, pneumonia and UTIs rates, while no definite conclusions can be drawn regarding CRBSIs.

Surgical patients carry a high overall risk of hospitalacquired infections (HAIs), mainly because SSIs occur in addition to non-surgery-specific infections [47]. Despite improvements in its prevention, SSI remains one of the most frequent and expensive preventable surgical complications, occurring in up to $20 \%$ of all abdominal procedures and significantly contributing to morbidity, risk of death and financial costs $[48,49]$. Of note, among surgical patients, even the risk of acquiring HAIs other than SSIs is significantly higher than in those patients who are not exposed to surgery, with pneumonia and UTIs being the most frequent complications [47].

In surgical setting, several factors contribute to the likelihood of infection, depending on the complex interplay between microbial (degree of contamination and virulence), patient (immune status), and procedural characteristics (length of procedure and amount of damage to tissues). Basically, infections arise from an imbalanced relationship between bacterial load and resistance of the host patient in the context of the procedure-induced systemic inflammatory response. Surgery per se weakens patient responsiveness, increasing the risk of infection because of the loss of integrity of skin and mucous membranes and the impairment of microbicidal activity of the immune cells [50]. In this setting, perioperative $\mathrm{DO}_{2}$ plays a critical role. It is well known 


\section{Pneumonia}

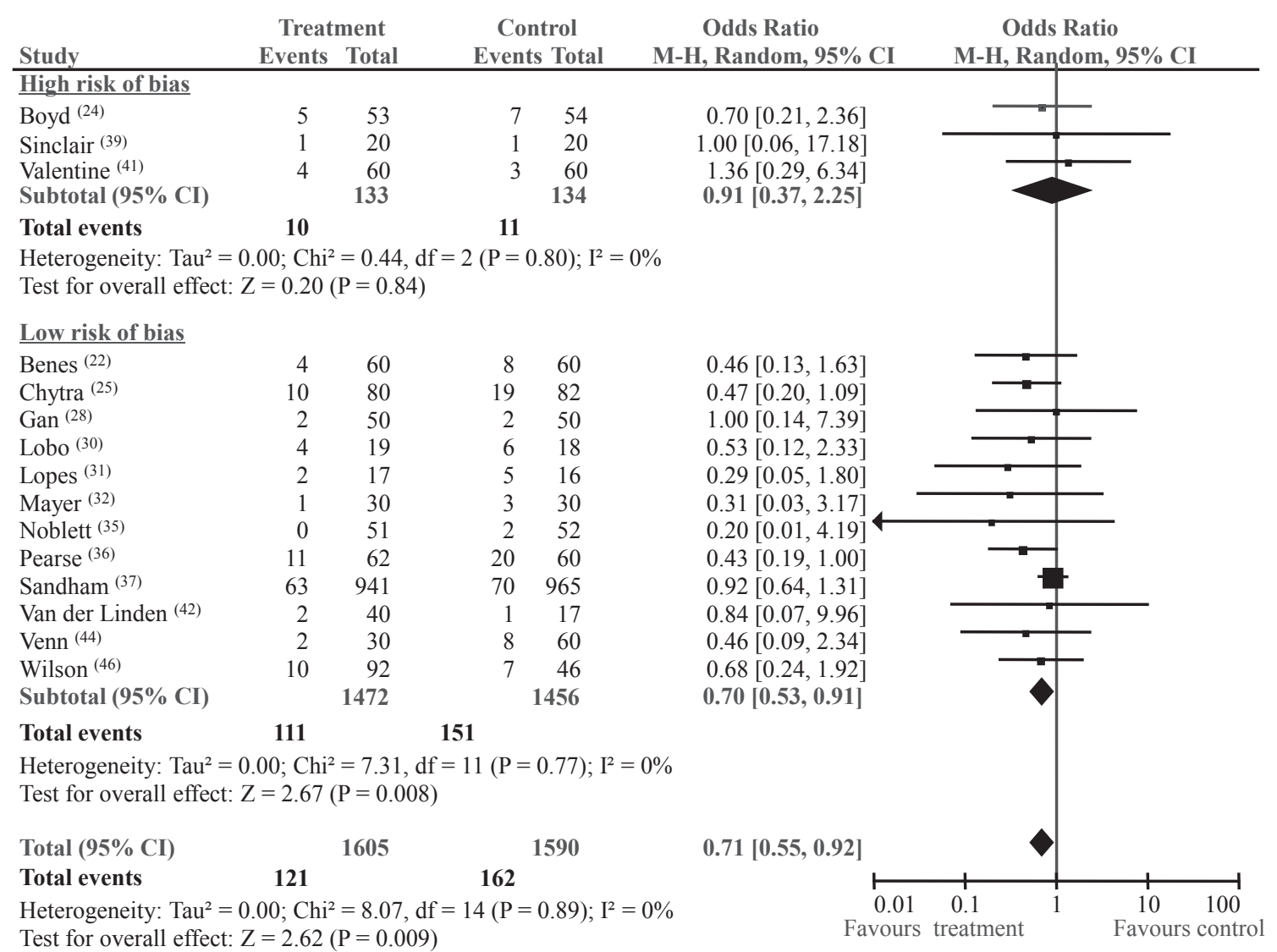

Figure 3 Pneumonia. Rates of postoperative pneumonia for each of the studies included are shown along with ORs and 95\% Cls. The studies were divided into two subgroups, high risk of bias and low risk of bias, according to the SIGN checklist (see text for details). The pooled OR and $95 \% \mathrm{Cl}$ are shown as the total. The size of the box at the point estimate of the OR gives a visual representation of the 'weighting' of the study. The diamond represents the point estimate of the pooled OR and the length of the diamond is proportional to the Cl. 95\% Cl: 95\% confidence interval; OR: odds ratio; SIGN: Scottish Intercollegiate Guidelines Network.

that adequate oxygen tissue levels promote wound healing and enhance resistance to infections [51-54]. This occurs because the oxidative burst function of neutrophils and the bacterial killing by alveolar macrophages, the primary defences against infection [55], both strictly depend on adequate oxygen tissue pressure $[51,56]$. Indeed, low tissue oxygen tension is among the bestestablished predictors of SSIs [57]. Thus, the maintenance of adequate tissue oxygen supply is a crucial step in promoting an appropriate immunological response to infection, especially in the setting of major surgery, which by itself leads to an increase in oxygen demand. Although high perioperative inspired oxygen administration represents an appealing tool, clear evidence for its beneficial effect has not yet been established. Of note, in the largest trial in which a high fraction of inspired oxygen has been tested, no influence on postoperative wound and pulmonary infections was observed [58].

In the present meta-analysis, we found that augmenting the bulk of $\mathrm{DO}_{2}$ by means of flow-directed therapy decreases postoperative infection rates. This finding has a pathophysiological foundation, at least theoretically. In the perioperative period, hypovolaemia and reduced cardiac output trigger musculocutaneous and splanchnic vasoconstriction, causing hypoperfusion and tissue hypoxia $[1,4,59]$, which weaken the mucosal immunological response and disrupt the gut barrier. Gut barrier failure could lead to sepsis by means of bacteria translocation and spillover of cytokines into the bloodstream, damaging distant tissues and altering the host immunological milieu [60]. In addition, gut ischaemia-reperfusion injury markedly impairs gut-associated lymphoid 


\section{Urinary tract infections}

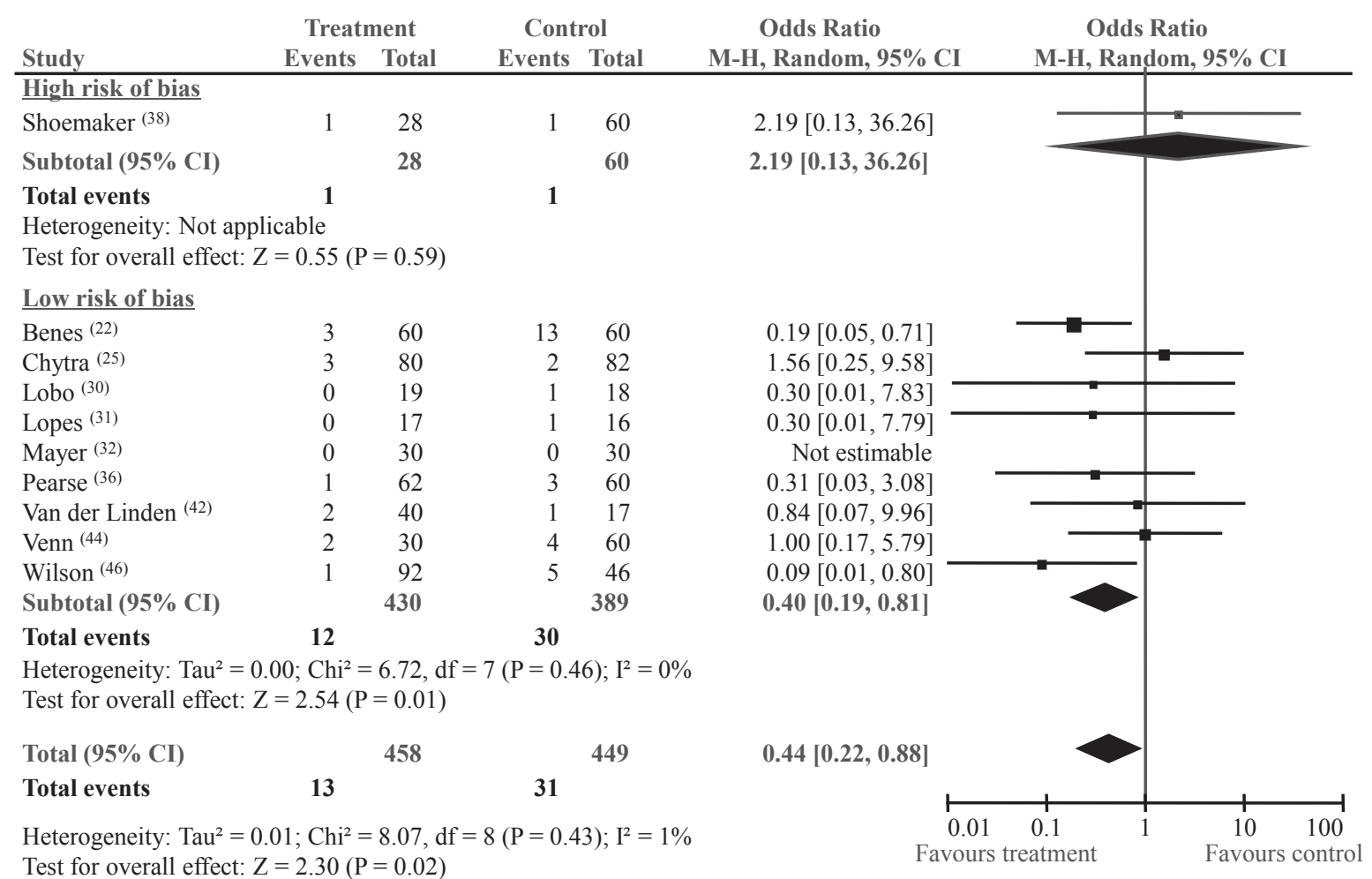

Figure 4 Urinary tract infections. Rates of postoperative urinary tract infections for each of the studies with ORs and 95\% Cls. The studies were divided into two subgroups defined as high risk of bias and low risk of bias, according to the SIGN checklist (see materials and methods section for details). The pooled OR and $95 \% \mathrm{Cl}$ data are shown as the totals. The size of the box at the point estimate of the OR is a visual representation of the 'weighting' of the study. The diamond represents the point estimate of the pooled OR, and the length of the diamond is proportional to the $95 \% \mathrm{Cl}$. 95\% Cl: $95 \%$ confidence interval; OR: odds ratio; SIGN: Scottish Intercollegiate Guidelines Network.

Table 2 Subgroup analysis for postoperative infective complications ${ }^{a}$

\begin{tabular}{|c|c|c|c|c|c|c|c|}
\hline Analysis & $\begin{array}{l}\text { Number of } \\
\text { studies }\end{array}$ & References & $\begin{array}{l}\text { Treatment } \\
\text { group } \\
\text { (episodes/total } \\
\text { patients) }\end{array}$ & $\begin{array}{c}\text { Control group } \\
\text { (episodes/total } \\
\text { patients) }\end{array}$ & $\begin{array}{l}\text { OR }(95 \% \\
\text { Cl) }\end{array}$ & $\begin{array}{c}P \\
\text { value }\end{array}$ & $I^{2}$ \\
\hline SSI high-risk patients & 13 & $\begin{array}{l}{[22],[24,25],[27],[30-32],} \\
{[34],[36-38],[44],[46]}\end{array}$ & $109 / 1,483$ & $177 / 1,522$ & $\begin{array}{l}0.48(0.33 \\
\text { to } 0.70)\end{array}$ & 0.0001 & $21 \%$ \\
\hline $\begin{array}{l}\text { SSI studies providing definitions } \\
\text { consistent with CDC criteria }\end{array}$ & 8 & $\begin{array}{l}{[22],[25],[30-32],[36],} \\
{[44,45]}\end{array}$ & $32 / 362$ & $74 / 390$ & $\begin{array}{l}0.37(0.23 \\
\text { to } 0.58)\end{array}$ & 0.0001 & $0 \%$ \\
\hline Pneumonia high-risk patients & 12 & $\begin{array}{l}\text { [22], [24,25], [30-32], [36,37], } \\
{[39],[42],[44],[46]}\end{array}$ & $115 / 1,444$ & $155 / 1,428$ & $\begin{array}{l}0.70(0.54 \\
\text { to } 0.91)\end{array}$ & 0.008 & $0 \%$ \\
\hline $\begin{array}{l}\text { Pneumonia studies providing definitions } \\
\text { consistent with CDC criteria }\end{array}$ & 9 & $\begin{array}{l}{[22],[25],[28],[30-32],} \\
{[36,37],[44]}\end{array}$ & $99 / 1,289$ & $141 / 1,341$ & $\begin{array}{l}0.70(0.53 \\
\text { to } 0.93)\end{array}$ & 0.01 & $0 \%$ \\
\hline UTI high-risk patients & 10 & $\begin{array}{l}{[22],[25],[30-32],[36],[38],} \\
{[42],[44],[46]}\end{array}$ & $13 / 458$ & $31 / 449$ & $\begin{array}{l}0.44(0.22 \\
\text { to } 0.88)\end{array}$ & 0.02 & $1 \%$ \\
\hline $\begin{array}{l}\text { UTI studies providing definitions } \\
\text { consistent with CDC criteria }\end{array}$ & 7 & [22], [25], [30-32], [36], [44] & $9 / 298$ & $24 / 326$ & $\begin{array}{l}0.45(0.20 \\
\text { to } 0.99)\end{array}$ & 0.05 & $0 \%$ \\
\hline
\end{tabular}

a $95 \%$ Cl: $95 \%$ confidence interval; CDC: Centers for Disease Control and Prevention; $P^{2}$ : inconsistency; OR: odds ratio; SSI: surgical site infection; UTI: urinary tract infection. 


\section{All infectious episodes}

\begin{tabular}{|c|c|c|c|c|c|c|c|}
\hline Study & \multicolumn{2}{|c|}{ Treatment } & \multicolumn{2}{|c|}{ Control } & $\begin{array}{l}\text { Odds Ratio } \\
\text { M-H, Random, } 95 \% \text { CI }\end{array}$ & \multicolumn{2}{|c|}{$\begin{array}{c}\text { Odds Ratio } \\
\text { M-H, Random, 95\% CI }\end{array}$} \\
\hline Bender $^{(21)}$ & 2 & 51 & 2 & 53 & $1.04[0.14,7.68]$ & & \\
\hline Benes ${ }^{(22)}$ & 13 & 60 & 49 & 60 & $0.06[0.03,0.15]$ & & \\
\hline Bishop ${ }^{(23)}$ & 3 & 50 & 12 & 65 & $0.28[0.07,1.06]$ & & \\
\hline Boyd (24) & 9 & 53 & 14 & 54 & $0.58[0.23,1.50]$ & & \\
\hline Chytra (25) & 22 & 80 & 36 & 82 & $0.48[0.25,0.93]$ & & \\
\hline Fleming (26) & 3 & 33 & 7 & 34 & $0.39[0.09,1.64]$ & & \\
\hline Forget $(27)$ & 14 & 41 & 15 & 41 & $0.90[0.36,2.22]$ & & \\
\hline $\operatorname{Gan}^{(28)}$ & 6 & 50 & 7 & 50 & $0.84[0.26,2.70]$ & & \\
\hline Jhanii (29) & 24 & 45 & 29 & 45 & $0.63[0.27,1.47]$ & & \\
\hline Lobo $^{(30)}$ & 6 & 19 & 11 & 18 & $0.29[0.08,1.14]$ & & \\
\hline Lopes ${ }^{(31)}$ & 5 & 17 & 11 & 16 & $0.19[0.04,0.84]$ & & \\
\hline Mayer (32) & 6 & 30 & 18 & 30 & $0.17[0.05,0.53]$ & & \\
\hline Mc Kendry ${ }^{(33)}$ & 2 & 89 & 5 & 85 & $0.37[0.07,1.95]$ & & \\
\hline Mythen ${ }^{(34)}$ & 0 & 30 & 1 & 30 & $0.32[0.01,8.24]$ & & \\
\hline Noblett (35) & 0 & 51 & 4 & 52 & $0.10[0.01,2.00]$ & & \\
\hline Pearse ${ }^{(36)}$ & 23 & 62 & 55 & 60 & $0.05[0.02,0.15]$ & & \\
\hline Sandham ${ }^{(37)}$ & 141 & 941 & 166 & 965 & $0.85[0.66,1.08]$ & & \\
\hline Shoemaker ${ }^{(38)}$ & 2 & 28 & 21 & 60 & $0.14[0.03,0.66]$ & & \\
\hline Sinclair ${ }^{(39)}$ & 1 & 20 & 1 & 20 & $1.00[0.06,17.18]$ & & \\
\hline Smetkin ${ }^{(40)}$ & 1 & 20 & 3 & 20 & $0.30[0.03,3.15]$ & & \\
\hline Valentine ${ }^{(41)}$ & 7 & 60 & 4 & 60 & $1.85[0.51,6.68]$ & & \\
\hline Van der Linden ${ }^{(42)}$ & 2 & 17 & 4 & 40 & $1.20[0.20,7.27]$ & & \\
\hline Velhamos ${ }^{(43)}$ & 16 & 40 & 18 & 35 & $0.63[0.25,1.57]$ & & \\
\hline Venn ${ }^{(44)}$ & 4 & 30 & 14 & 30 & $0.18[0.05,0.63]$ & & \\
\hline Wakeling (45) & 19 & 64 & 18 & 64 & $1.08[0.50,2.32]$ & & \\
\hline Wilson ${ }^{(46)}$ & 28 & 92 & 25 & 46 & $0.37[0.18,0.76]$ & & \\
\hline Total $(95 \%$ CI) & & 2073 & & 2115 & $0.40[0.28,0.58]$ & & \\
\hline Total events & 359 & & $\mathbf{5 5 0}$ & & & & \\
\hline $\begin{array}{l}\text { Heterogeneity: Tau } \\
\text { Test for overall effe }\end{array}$ & $\begin{array}{l}52 ; \mathrm{Chi}^{2} \\
=4.77(\mathrm{H}\end{array}$ & $\begin{array}{l}=80.7 \\
P<0.0\end{array}$ & $=25(\mathrm{P}$ & $<0.00$ & $=69 \%$ & $\mathrm{~m}$ & $\begin{array}{c}10 \\
\text { Favours }\end{array}$ \\
\hline
\end{tabular}

Figure 5 Total postoperative infectious episodes. Rates of total postoperative infectious episodes for each of the studies included are shown along with ORs and $95 \% \mathrm{Cls}$. The pooled OR and $95 \% \mathrm{Cl}$ data are shown as the totals. The size of the box at the point estimate of the OR is a visual representation of the 'weighting' of the study. The diamond represents the point estimate of the pooled OR, and the length of the diamond is proportional to the $95 \% \mathrm{Cl}$. $95 \% \mathrm{Cl}$ : $95 \%$ confidence interval; OR: odds ratio.

tissue (GALT), further weakening extraintestinal mucosal immunity and therefore contributing to the patient's increased susceptibility to infections $[60,61]$.

A flow-directed haemodynamic therapy aimed at optimising $\mathrm{DO}_{2}$ by preserving or increasing cardiac output may preserve the microbicidal function of immune cells and may protect organs particularly at risk for perioperative hypoperfusion [8], avoiding gut barrier failure and GALT impairment. Our results substantiate these concepts, demonstrating that perioperative GDT using fluid loading and/or inotropic supports to prevent tissue hypoxia could protect surgical patients against SSIs, pneumonia and UTIs.

No study has specifically assessed the effects of preserving cardiac output on SSI rates, although investigators in a recent meta-analysis concluded that supplemental hydration by itself, regardless of any specific haemodynamic target, does not affect the wound infection rate
[62]. However, when the amount of perioperatively administered fluids is aimed at increasing subcutaneous oxygen tension, a greater amount of collagen in wound healing has been observed [63].

Even if the pathophysiology of postoperative pneumonia after major surgery is undoubtedly complex and multifactorial [64-66], gut failure and bacterial translocation through the lymphatics and thoracic ducts [67] and impaired respiratory mucosal immunity by a decrease in $\mathrm{DO}_{2}$ may have a potential pathogenetic role [68-70]. Our data seem to support this hypothesis: out of $15 \mathrm{stu}-$ dies reporting pneumonia, 13 involved abdominal surgery, which is itself a predisposing factor for gut hypoperfusion [71]. It is reasonable to argue that GDT, by ensuring adequate systemic oxygenation, can protect against ischaemia-reperfusion injury, thus decreasing the incidence of respiratory tract infections after severe surgical insults. 
In surgical patients, flow-directed haemodynamic therapy aimed at optimising $\mathrm{DO}_{2}$ represents a useful strategy to prevent HAIs. Therefore, perioperative GDT must be strongly encouraged, particularly in high-risk surgical patients [72-74], in whom the likelihood of such complications is great.

\section{Limitations}

The main limitations of all meta-analyses include reporting bias and the clinical and methodological heterogeneity of the included studies. To reduce reporting bias, we attempted to identify, retrieve and include all reports, grey and published [75], that met predefined inclusion criteria, and to retrieve unpublished data by contacting the authors of the included studies. No unpublished results were retrieved, and two abstracts $[76,77]$ were identified, but they did not report the incidence of postoperative infections. Therefore, we cannot exclude the possible existence of any publication bias, and available statistical tests are not accurate enough to detect it [78].

All the studies of perioperative haemodynamic optimisation had the same starting point, fluid loading, and the same end point, achieving adequate $\mathrm{DO}_{2}$. However, the included studies varied in their approaches to the timing and modalities of interventions, the therapeutic targets, the monitoring tools used and the type of patients enrolled. Therefore, the clinical heterogeneity of the studies included in the present meta-analysis may be relatively high, although the statistical heterogeneity was low and the main results remained consistent across a number of subgroups and sensitivity analyses.

The paper by Mayer et al. [32] has been under investigation for ethical reasons because of its link to J Boldt. However, differently from other papers, their article had Institutional Review Board approval, and its publication was not retracted. Therefore, since it remained part of the scientific record at the time we searched the literature, we had no sound reason to remove this paper from our meta-analysis. However, to verify potential biases in our results, all data were reexamined without including the Mayer et al. [32] paper, and no differences were found.

Each type of infection (SSI, pneumonia, CRBSI and UTI) was considered separately, and a quality sensitive analysis was performed, including studies with low risk of bias (SIGN evaluation + or ++ ). Considering SSIs, the 14 studies reaching a low risk of bias evaluation drove the significant effect of GDT in reducing wound infections, assuring reliable and consistent evidence-based results. The four trials with a high risk of bias did not demonstrate significant results. For pneumonia, 12 of 15 studies reached a low risk of bias evaluation: The quality-sensitive analysis including only these studies confirmed the main result. The lack of outcome definition is another critical source of bias. In 10 and 6 studies, respectively, of the present meta-analysis, SSI and pneumonia were not defined. When we pooled only the studies in which the definition of SSI and pneumonia was consistent with the CDC criteria, the analyses confirmed the main results.

The pathogenesis of postoperative infections is multifactorial, involving the type of surgery, bacterial contamination and host response. Surgery itself and surgical gut manipulation are major proinflammatory stimuli [71]. All anaesthetic drugs, especially the opioids, have the potential to contribute to decreased immune response [79]. Moreover, glucose and electrolyte imbalance and hypothermia may affect immune function. We cannot state how all these conditions, comorbidities, antibiotic prophylaxis and iatrogenic interventions interact to determine infectious complications in the postoperative period.

Regarding the overall number of infectious episodes, methodological differences, including the control of covariates and, above all, the extreme variability in outcomes, may explain the presence of statistical heterogeneity and inconsistency in this result. No significant differences in CRBSIs were observed between the GDT and control groups. The very low statistical power of these analyses, owing to the low event rate, may explain this finding and does not allow us to draw any meaningful clinical conclusions, so further trials are needed.

\section{Research agenda}

Because of the variability in methodologies and definitions of infections between studies, further prospective, randomised, controlled studies are warranted to investigate the relationship between haemodynamic GDT and infection reduction. Specifically, further studies should incorporate a rigorous protocol that includes all evidence-based approaches to reducing postoperative infections, standardises perioperative haemodynamic management and adopts a widely accepted and clinically relevant definition of 'postoperative infection' for each specific site as a primary end point. Moreover, since very recent evidence [80] supports clinical benefits and cost savings of GDT when an oesophageal Doppler monitor is used in high-risk surgical patients, further research should be done to investigate the specific role of this less invasive monitoring device in reducing postoperative infections.

\section{Conclusions}

Infection surveillance, control and prevention systems have been developed at many centres worldwide, and numerous guidelines have been published and 
implemented in the effort to reduce the incidence of infections. Despite these measures, the clinical and economic burden of postoperative infections remains significant $[1,2]$. Our meta-analysis, within the limitations of existing data and the analytic approaches used, shows that GDT is an effective tool in reducing the incidence of infectious complications, and, more specifically, that GDT significantly decreases the rate of SSIs, pneumonia and UTIs. During surgery, GDT, by preserving or increasing cardiac output, may protect patients against severe gut ischaemia-reperfusion injury and GALT impairment, thus decreasing the incidence of postoperative infections. Hence, this strategy must be strongly encouraged. Continuing investigations into this fundamental area are warranted to better understand the link between haemodynamic optimisation and improved outcomes in surgical patients.

\section{Key messages}

- In surgical patients, a flow-directed haemodynamic therapy aimed to optimise $\mathrm{DO}_{2}$ could be a useful strategy to prevent hospital-acquired infections.

- Specifically, goal-directed haemodynamic therapy significantly decreases the rate of surgical site infections, pneumonia and urinary tract infections.

- Thus, this strategy must be strongly encouraged, particularly in the setting of surgical patients at high risk for infections.

- Continuing investigations into this area are warranted to better clarify the link between haemodynamic optimisation and improved outcome in surgical patients.

\section{Additional material}

Additional file 1: Strategies used to search the MEDLINE, Cochrane Library and EMBASE databases.

\begin{abstract}
Abbreviations
ASA: American Society of Anesthesiologists; CDC: Centers for Disease Control and Prevention; Cl: confidence interval; CRBSI: catheter-related bloodstream infections; $\mathrm{DO}_{2}$ : oxygen delivery; GALT: gut-associated lymphoid tissue; GDT: goal-directed therapy; HAl: hospital-acquired infection; NNT: number needed to treat; OR: odds ratio; RCT: randomised, controlled trial; SIGN: Scottish Intercollegiate Guidelines Network; SSI: surgical site infection; UTI: urinary tract infection.
\end{abstract}

\footnotetext{
Authors' contributions

LD carried out the primary study search, rechecked data and drafted and revised the manuscript. MTG extracted data, performed statistical analysis and helped to draft the manuscript. FP carried out the primary study search, rechecked data and helped to draft the manuscript. MM extracted data, tabulated quality indicators of the studies and helped to draft the manuscript. NB conceived of the study, participated in its design and coordination, extracted data and drafted and revised the manuscript. All authors read and approved the final manuscript.
}

\section{Competing interests}

The authors declare that they have no competing interests.

Received: 8 April 2011 Revised: 23 May 2011 Accepted: 24 June 2011 Published: 24 June 2011

\section{References}

1. Pessaux P, Msika S, Atalla D, Hay JM, Flamant Y, French Association for Surgical Research: Risk factors for postoperative infectious complications in noncolorectal abdominal surgery: a multivariate analysis based on a prospective multicenter study of 4718 patients. Arch Surg 2003, 138:314-324

2. Farid SG, Aldouri A, Morris-Stiff G, Khan AZ, Toogood GJ, Lodge JPA, Prasad KR: Correlation between postoperative infective complications and long-term outcomes after hepatic resection for colorectal liver metastasis. Ann Surg 2010, 251:91-100.

3. Anderson DJ, Kaye KS, Classen D, Arias KM, Podgorny K, Burstin $H_{\text {, }}$ Calfee DP, Coffin SE, Dubberke ER, Fraser V, Gerding DN, Griffin FA, Gross P, Klompas M, Lo E, Marschall J, Mermel LA, Nicolle L, Pegues DA, Perl TM, Saint S, Salgado CD, Weinstein RA, Wise R, Yokoe DS: Strategies to prevent surgical site infections in acute care hospitals. Infect Control Hosp Epidemiol 2008, 29:S51-S61.

4. Chappell D, Jacob M, Hofmann-Kiefer K, Conzen P, Rehm M: A Rational approach to perioperative fluid management. Anesthesiology 2008, 109:723-740.

5. Shoemaker WC, Appel PL, Kram HB: Haemodynamic and oxygen transport responses in survivors and nonsurvivors of high-risk surgery. Crit Care Med 1993, 21:977-990.

6. Kern JW, Shoemaker WC: Meta-analysis of hemodynamic optimization in high-risk patient. Crit Care Med 2002, 30:1686-1692.

7. Brienza N, Giglio MT, Marucci M, Fiore T: Does perioperative hemodynamic optimization protect renal function in surgical patients? A meta-analytic study. Crit Care Med 2009, 37:2079-2090.

8. Giglio MT, Marucci M, Testini M, Brienza N: Goal-directed haemodynamic therapy and gastrointestinal complications in major surgery: a metaanalysis of randomized controlled trials. Br J Anaesth 2009, 103:637-646.

9. Moher D, Liberati A, Tetzlaff J, Altman DG, PRISMA Group: Preferred Reporting Items for Systematic Reviews and Meta-Analyses: the PRISMA statement. BMJ 2009, 339:b2535.

10. Lefebvre C, Manheimer E, Glanville J: Searching for studies. In Cochrane Handbook for Systematic Reviews of Interventions Version 5.0.1. Volume Chapter 6. Edited by: Higgins JPT, Green S. The Cochrane Collaboration (updated September 2008); [http://www.cochrane-handbook.org/].

11. Copeland GP, Jones D, Walters M: POSSUM: a scoring system for surgical audit. Br J Surg 1991, 78:355-360.

12. SIGN 50: A Guideline Developer's Handbook. [http://www.sign.ac.uk/ guidelines/fulltext/50/index.html].

13. Jadad AR, Moore RA, Carroll D, Jenkinson C, Reynolds DJ, Gavaghan DJ, McQuay HJ: Assessing the quality of randomized clinical trials: is blinding necessary? Control Clin Trials 1996, 17:1-12.

14. Jüni $P$, Witschi $A$, Bloch $R$, Egger M: The hazards of scoring the quality of clinical trials for meta-analysis. JAMA 1999, 282:1054-1060.

15. Higgins JPT, Altman DG: Assessing risk of bias in included studies. In Cochrane Handbook for Systematic Reviews of Interventions Version 5.0.1. Volume Chapter 8. Edited by: Higgins JPT, Green S. The Cochrane Collaboration (updated September 2008); [http://www.cochrane-handbook. org/].

16. Horan TC, Gaynes RP: Surveillance of nosocomial infections. In Hospital Epidemiology and Infection Control.. 3 edition. Edited by: Mayall CG. Philadelphia: Lippincott Williams and Wilkins; 2004:1659-1702.

17. Higgins JPT, Thompson SG: Quantifying heterogeneity in a meta-analysis. Stat Med 2002, 21:1539-1558.

18. Higgins JPT, Thompson SG, Deeks JJ, Altman DG: Measuring inconsistency in meta-analyses. BMJ 2003, 327:557-560.

19. Deeks JJ, Higgins JPT, Altman DG: Analysing data undertaking metaanalyses. In Cochrane Handbook for Systematic Reviews of Interventions. Version 5.0.1. Volume Chapter 9. Edited by: Higgins JPT, Green S. The Cochrane Collaboration (updated September 2008); [http://www.cochranehandbook.org/].

20. Fletcher J: What is heterogeneity and is it important? BMJ 2007, 334:94-96. 
21. Bender JS, Smith-Meek MA, Jones CE: Routine pulmonary artery catheterization does not reduce morbidity and mortality of elective vascular surgery: results of a prospective, randomized trial. Ann Surg 1997, 226:229-236

22. Benes J, Chytra I, Altmann P, Hluchy M, Kasal E, Svitak R, Pradl R, Stepan M: Intraoperative fluid optimization using stroke volume variation in high risk surgical patients: results of prospective randomized study. Crit Care 2010, 14:R118

23. Bishop MH, Shoemaker WC, Appel PL, Meade P, Ordog GJ, Wasserberger J, Wo CJ, Rimle DA, Kram HB, Umali R, Kennedy F, Shuleshko J, Stephen CM, Shori SK, Thadepalli HD: Prospective randomized trial of survivor values of cardiac index, oxygen delivery, and oxygen consumption as resuscitation endpoints in severe trauma. J Trauma 1995, 38:780-787.

24. Boyd O, Grounds M, Bennett D: A randomized clinical trial of the effect of deliberate perioperative increase of oxygen delivery on mortality in high-risk surgical patients. JAMA 1993, 270:2699-2708.

25. Chytra I, Pradl R, Bosman R, Pelnár P, Kasal E, Zidková A: Esophageal Doppler-guided fluid management decreases blood lactate levels in multiple-trauma patients: a randomized controlled trial. Crit Care 2007, 11:R24.

26. Fleming A, Bishop M, Shoemaker W, Appel P, Sufficool W, Kuvhenguwha A, Kennedy F, Wo CJ: Prospective trial of supranormal values as goals of resuscitation in severe trauma. Arch Surg 1992, 127:1175-1181.

27. Forget $P$, Lois $F$, de Kock M: Goal-directed fluid management based on the pulse oximeter-derived Pleth variability index reduces lactate levels and improves fluid management. Anesth Analg 2010, 111:910-914.

28. Gan TJ, Soppitt A, Maroof M, el-Moalem H, Robertson KM, Moretti E, Dwane P, Glass PS: Goal-directed intraoperative fluid administration reduces length of hospital stay after major surgery. Anesthesiology 2002, 97:820-826.

29. Jhanji S, Vivian-Smith A, Lucena-Amaro S, Watson D, Hinds C, Pearse R: Haemodynamic optimisation improves tissue microvascular flow and oxygenation after major surgery: a randomised controlled trial. Crit Care 2010, 14:R151.

30. Lobo SM, Salgado PF, Castillo VG, Borim AA, Polachini CA, Palchetti JC, Brienzi SL, de Oliveira GG: Effects of maximizing oxygen delivery on morbidity and mortality in high-risk surgical patients. Crit Care Med 2000, 28:3396-3404.

31. Lopes M, Oliveira M, Pereira V, Lemos IP, Auler JO Jr, Michard F: Goaldirected fluid management based on pulse pressure variation monitoring during high-risk surgery: a pilot randomized controlled trial. Crit Care 2007, 11:R100

32. Mayer J, Boldt J, Mengistu AM, Röhm KD, Suttner S: Goal-directed intraoperative therapy based on autocalibrated arterial pressure waveform analysis reduces hospital stay in high-risk surgical patients: a randomized, controlled trial. Crit Care 2010, 14:R18.

33. McKendry M, McGloin $H$, Saberi $D$, Caudwell $L$, Brady AR, Singer $M$ : Randomised controlled trial assessing the impact of a nurse delivered, flow monitored protocol for optimisation of circulatory status after cardiac surgery. BMJ 2004, 329:258

34. Mythen MG, Webb AR: Perioperative plasma volume expansion reduces the incidence of gut mucosal hypoperfusion during cardiac surgery. Arch Surg 1995, 130:423-429.

35. Noblett SE, Snowden CP, Shenton BK, Horgan AF: Randomized clinical trial assessing the effect of Doppler-optimized fluid management on outcome after elective colorectal resection. Br J Surg 2006, 93:1069-1076.

36. Pearse R, Dawson D, Fawcett J, Rhodes A, Grounds RM, Bennett ED: Early goal-directed therapy after major surgery reduces complications and duration of hospital stay: a randomised, controlled trial. Crit Care 2005, 9:687-693

37. Sandham JD, Hull RD, Brant RF, Knox L, Pineo GF, Doig CJ, Laporta DP, Viner S, Passerini L, Devitt H, Kirby A, Jacka M, Canadian Critical Care Clinical Trials Group: A randomized, controlled trial of the use of pulmonaryartery catheters in high-risk surgical patients. N Engl J Med 2003, 348:5-14.

38. Shoemaker WC, Appel PL, Kram HB, Waxman K, Lee TS: Prospective trial of supranormal values of survivors as therapeutic goals in high-risk surgical patients. Chest 1988, 94:1176-1186.

39. Sinclair $S$, James $S$, Singer M: Intraoperative intravascular volume optimisation and length of hospital stay after repair of proximal femoral fracture: randomised controlled trial. BMJ 1997, 315:909-912.
40. Smetkin AA, Kirov MY, Kuzkov VV, Lenkin Al, Eremeev AV, Slastilin VY, Borodin $\mathrm{W}$, Bjertnaes $\mathrm{LJ}$ : Single transpulmonary thermodilution and continuous monitoring of central venous oxygen saturation during off-pump coronary surgery. Acta Anaesthesiol Scand 2009, 53:505-514

41. Valentine RJ, Duke ML, Inman MH, Grayburn PA, Hagino RT, Kakish HB, Clagett GP: Effectiveness of pulmonary artery catheters in aortic surgery: a randomized trial. J Vasc Surg 1998, 27:203-212.

42. Van der Linden PJ, Dierick A, Wilmin S, Bellens B, De Hert G: A randomized controlled trial comparing an intraoperative goal-directed strategy with routine clinical practice in patients undergoing peripheral arterial surgery. Eur J Anaesthesiol 2010, 27:788-793.

43. Velmahos GC, Demetriades D, Shoemaker WC, Chan LS, Tatevossian R, Wo CC, Vassiliu P, Cornwell EE, Murray JA, Roth B, Belzberg H, Asensio JA, Berne TV: Endpoints of resuscitation of critically injured patients: normal or supranormal? A prospective randomized trial. Ann Surg 2000, 232:409-418

44. Venn R, Steele A, Richardson P, Poloniecki J, Grounds M, Newman P: Randomized controlled trial to investigate influence of the fluid challenge on duration of hospital stay and perioperative morbidity in patients with hip fractures. Br J Anaesth 2002, 88:65-67.

45. Wakeling HG, McFall MR, Jenkins CS, Woods WG, Miles WF, Barclay GR, Fleming SC: Intraoperative oesophageal Doppler guided fluid management shortens postoperative hospital stay after major bowel surgery. Br J Anaesth 2005, 95:634-642.

46. Wilson J, Woods I, Fawcett J, Whall R, Dibb W, Morris C, McManus E: Reducing the risk of major elective surgery: randomised controlled trial of preoperative optimisation of oxygen delivery. BMJ 1999, 318:1099-1103.

47. Sax H, Uçkay I, Balmelli C, Bernasconi E, Boubaker K, Mühlemann K, Ruef C, Troillet N, Widmer A, Zanetti G, Pittet D: Overall burden of healthcareassociated infections among surgical patients: results of a national study. Ann Surg 2011, 253:365-370.

48. Kurz A, Sessler DI, Lenhardt RA: Study of wound infections and temperature group: perioperative normothermia to reduce the incidence of surgical-wound infection and shorten hospitalization. $N$ Engl J Med 1996, 334:1209-1215.

49. Haley RW, Culver DH, Morgan WM, White JW, Emori TG, Hooton TM: Identifying patients at high risk of surgical wound infection: a simple multivariate index of patient susceptibility and wound contamination. Am J Epidemiol 1985, 121:206-215.

50. El-Maallem H, Fletcher J: Effects of surgery on neutrophil granulocyte function. Infect Immun 1981, 32:38-41.

51. Hopf HW, Hunt TK, West JM, Blomquist P, Goodson WH, Jensen JA, Jonsson K, Paty PB, Rabkin JM, Upton RA, von Smitten K, Whitney JD: Wound tissue oxygen tension predicts the risk of wound infection in surgical patients. Arch Surg 1997, 132:997-1007.

52. Hohn DC, Mackay RD, Halliday BJ, Hunt TK: Effect of $\mathrm{O}_{2}$ tension on microbicidal function of leukocytes in wounds and in vitro. Surg Forum 1976, 27:18-20.

53. Jonsson K, Jensen JA, Goodson WH, Scheuenstuhl H, West J, Hopf HW, Hunt TK: Tissue oxygenation, anemia and perfusion in relation to wound healing in surgical patients. Ann Surg 1991, 214:605-613.

54. Knighton DR, Halliday BJ, Hunt TK: Oxygen as an antibiotic: the effect of inspired oxygen on infection. Arch Surg 1984, 119:199-204.

55. Allen DB, Maguire JJ, Mahdavian M, Wicke C, Marcocci L, Scheuenstuhl H, Chang M, Le AX, Hopf HW, Hunt TK: Wound hypoxia and acidosis limit neutrophil bacterial killing mechanisms. Arch Surg 1997, 132:991-996.

56. Babior BM: Oxygen-dependent microbial killing by phagocytes (first of two parts). N Engl J Med 1978, 298:659-668

57. Govinda R, Kasuya Y, Bala E, Mahboobi R, Devarajan J, Sessler DI, Akça O: Early postoperative subcutaneous tissue oxygen predicts surgical site infection. Anesth Analg 2010, 111:946-952.

58. Meyhoff CS, Wetterslev J, Jorgensen LN, Henneberg SW, Høgdall C, Lundvall L, Svendsen PE, Mollerup H, Lunn TH, Simonsen I, Martinsen KR, Pulawska T, Bundgaard L, Bugge L, Hansen EG, Riber C, Gocht-Jensen P, Walker LR, Bendtsen A, Johansson G, Skovgaard N, Heltø K, Poukinski A, Korshin A, Walli A, Bulut M, Carlsson PS, Rodt SA, Lundbech LB, Rask H, PROXI Trial Group, et al: Effect of high perioperative oxygen fraction on surgical site infection and pulmonary complications after abdominal surgery: the PROXI randomized clinical trial. JAMA 2009, 302:1543-1550. 
59. Miles AA, Miles EM, Burke J: The value and duration of defence reactions of the skin to the primary lodgement of bacteria. Br J Exp Pathol 1957, 38:79-96.

60. Holland J, Carey M, Hughes N, Sweeney K, Byrne PJ, Healy M, Ravi N, Reynolds JV: Intraoperative splanchnic hypoperfusion, increased intestinal permeability, down-regulation of monocyte class II major histocompatibility complex expression, exaggerated acute phase response, and sepsis. Am J Surg 2005, 190:393-400.

61. Clark JA, Coopersmith CM: Intestinal crosstalk: a new paradigm for understanding the gut as the "motor" of critical illness. Shock 2007, 28:384-393.

62. Kabon B, Akça O, Taguchi A, Nagele A, Jebadurai R, Arkilic CF, Sharma N, Ahluwalia A, Galandiuk S, Fleshman J, Sessler DI, Kurz A: Supplemental intravenous crystalloid administration does not reduce the risk of surgical wound infection. Anesth Analg 2005, 101:1546-1553.

63. Hartmann $M$, Jönsson $K$, Zederfeldt B: Effect of tissue perfusion and oxygenation on accumulation of collagen in healing wounds. Randomized study in patients after major abdominal operations. Eur J Surg 1992, 158:521-526.

64. Kotani N, Takahashi S, Sessler DI, Hashiba E, Kubota T, Hashimoto H, Matsuki A: Volatile anesthetics augment expression of proinflammatory cytokines in rat alveolar macrophages during mechanical ventilation. Anesthesiology 1999, 91:187-197.

65. Kotani N, Lin CY, Wang JS, Gurley JM, Tolin FP, Michelassi F, Lin HS, Sandberg WS, Roizen MF: Loss of alveolar macrophages during anesthesia and operation in humans. Anesth Analg 1995, 81:1255-1262

66. Kotani N, Hashimoto H, Sessler DI, Kikuchi A, Suzuki A, Takahashi S, Muraoka M, Matsuki A: Intraoperative modulation of alveolar macrophage during isoflurane and propofol anesthesia. Anesthesiology 1998, 89:1125-1132

67. Fiddian-Green RG, Baker S: Nosocomial pneumonia in the critically ill: product of aspiration or translocation? Crit Care Med 1991, 19:763-769.

68. Kusano C, Baba M, Takao S, Sane S, Shimada M, Shirao K, Natsugoe S, Fukumoto T, Aikou T: Oxygen delivery as a factor in the development of fatal postoperative complications after oesophagectomy. Br J Surg 1997, 84:252-257.

69. Kudsk KA, Li J, Renegar KB: Loss of upper respiratory tract immunity with parenteral feeding. Ann Surg 1996, 223:629-635.

70. Fukatsu K, Sakamoto S, Hara E, Ueno C, Maeshima Y, Matsumoto I, Mochizuki $H$, Hiraide $H$ : Gut ischemia-reperfusion affects gut mucosal immunity: a possible mechanism for infectious complications after severe surgical insult. Crit Care Med 2006, 34:182-187.

71. Sido B, Teklote JR, Hartel M, Friess $H$, Büchler MW: Inflammatory response after abdominal surgery. Best Pract Res Clin Anaesthesiol 2004, 18:439-454.

72. Pearse RM, Harrison DA, James P, Watson D, Hinds C, Rhodes A Grounds RM, Bennett ED: Identification and characterisation of the highrisk surgical population in the United Kingdom. Crit Care 2006, 10:R81.

73. Boyd $\mathrm{O}$, Jackson $\mathrm{N}$ : Clinical review: how is risk defined in high-risk surgical patient management? Crit Care 2005, 9:390-396.

74. Lees N, Hamilton M, Rhodes A: Clinical review: goal-directed therapy in high risk surgical patients. Crit Care 2009, 13:231.

75. McAuley L, Pham B, Tugwell P, Moher D: Does the inclusion of grey literature influence estimates of intervention effectiveness reported in meta-analyses? Lancet 2000, 356:1228-1231.

76. Wijayasiri L, Garewal D, Khpal M, Rhodes A, Dewhurst A, Cecconi M: Does stroke volume increase after a fluid challenge? A study on the management of patients undergoing major head and neck free flap surgery: preliminary data [abstract]. Crit Care 2010, 14(Suppl 1):P119.

77. Ramsingh D, Gamboa J, Applegate R: Evaluation of a goal directed protocol in low-moderate risk patients having major abdominal surgery [abstract A1137]. Proceedings of the 2010 Annual Meeting of the American Society of Anesthesiologists San Diego, CA, USA; 2010.

78. Lau J, loannidis JP, Terrin N, Schmid CH, Olkin I: The case of the misleading funnel plot. BMJ 2006, 333:597-600.

79. Sacerdote P: Opioids and the immune system. Palliat Med 2006, 20(Suppl 1):s9-s15.

80. National Institute for Health and Medical Excellence: CardioQ-ODM oesophageal Doppler monitor. [http://www.nice.org.uk/guidance/MTG3].

doi: $10.1186 /$ cc10284

Cite this article as: Dalfino et al:: Haemodynamic goal-directed therapy and postoperative infections: earlier is better. a systematic review and meta-analysis. Critical Care 2011 15:R154.

\section{Submit your next manuscript to BioMed Central and take full advantage of:}

- Convenient online submission

- Thorough peer review

- No space constraints or color figure charges

- Immediate publication on acceptance

- Inclusion in PubMed, CAS, Scopus and Google Scholar

- Research which is freely available for redistribution

Submit your manuscript at www.biomedcentral.com/submit
Biomed Central 